\title{
Democracy at the Grassroots
}

\author{
By: Akshay Singh
}

\section{Abstract}

The social, economic and political conditions prevalent at the time of the independence had cast great aspersions on the future of India as a country. But, almost eighty years, since the forecasts of gloom, the country has surprised many. Today, it has established itself as the largest democracy in the world. However, the rising inequality in the country is becoming a threat to the people living at the margins. Inequality is multi-dimensional and should not be understood only as income inequality. In India, the synthesis of inequalities which emanate from fissures in caste, class, and gender become a bane for the ones living at the margins. It is not to say that the successive governments have been oblivious to the amelioration of inequality, but the institutions have not functioned efficiently. The poor need and deserve equitable provisioning of public goods like sanitation services, electricity, health-care, education to alleviate their suffering while at the same time they need institutions which give them some sort of legitimacy or authority to hold political institutions responsible to demand these rights. Establishment of institutions at the community level can be a way to address the inequality which the poor face and it would also improve the credibility of the existing political institutions. The institutional design should safeguard the representation of the different demographics, the setting should not intimidate people from not participating which would stop the iron law of oligarchy from reinforcing itself.

\footnotetext{
"In a democracy, the well-being, individuality and happiness of every citizen is important for the overall prosperity, peace and happiness of the nation" - A. P. J. Abdul Kalam
}

\section{Introduction}

Around the 1940 s the state of poverty and hunger in India was so exemplary that it made way to dinner tables in European and American homes to discourage the children from wasting food (Drèze \& Sen, 2013). India, born in 1947 still remains an eclectic mix of rich cultures and languages along with the plurality of religion and caste. From a manufactured dominion of states to an eight decade-old democracy, it has made some giant strides to allay the forecasts of gloom. 
According to World Bank estimates, the value of the Indian economy at the end of the first decade of independence was around one-hundred and forty-nine billion USD. In contrast, today the country is the seventh-largest economy in the world with a growth rate of around seven per cent. The infant mortality rate has become one-fifth; the adult literacy rate has improved by almost thirty-five percentage points while the life expectancy has nearly doubled. However, the democratic performance of the country has not come about without any blips and blemishes. Even though the Emergency of 1975 has become synonymous with the comprise of the democratic ideals, instances of communal riots and corruption equally take the sheen away. But, on a more microscopic level, the equality of the citizens, especially those who live at the margins, continues to erode. It is not to say that the successive governments have been oblivious to the amelioration of inequality, but the institutions have either not functioned efficiently or the existing mechanisms have been inadequate to render social democracy in India. Inequalities manifest themselves in various ways. It erodes the citizen participation and, in some cases, systemically excludes it thereby encroaching on this essential democratic principle. Through the essay, I would bring forth the importance of community-level democratic institutions and how they would work towards breaking the vicious circle of inequality.

\section{Scourge of Inequality}

$$
\begin{aligned}
& \text { "Massive poverty and obscene inequality are such terrible scourges of our } \\
& \text { times - times in which the world boasts breathtaking advances in science, } \\
& \text { technology, industry, and wealth accumulation - that they have to rank } \\
& \text { alongside slavery and apartheid as social evils." }
\end{aligned}
$$

- Nelson Mandela

The economic and social disparity between the rich and the poor acts as a buffer against the enhancement of capabilities and freedoms of the people who live at the margins. Income inequality manifests itself in the life of humans often as poverty. Poverty is multi-dimensional, and it should not be just understood from the definition of living on less than one dollar a day (UNESCO, n.d.). Poverty brings along with itself a "sense of powerlessness, frustration, exhaustion, and exclusion from decisionmaking" which often acts as a blockade in accessing sanitation, health, education and other services (Green, Fried, \& Sen, 2013, p. 7). The poor living at the margin of the 
society or below it often become invisible to political institutions while the poor treat whatever is happening to them as fait accompli. A World Bank report suggested that the income inequality in India was on the rise and the inequality might be at the level of Brazil and South Africa, countries synonymous with high levels of inequality (World Bank, 2011). The poor are not only unequal on the basis of their incomes but the synchronisation of the multifarious inequalities at play in the country make the situation, bleaker.

\section{Multi-dimensional Inequality}

The discrimination in terms of caste, class and gender pose a specific challenge in the Indian setting because they mutually reinforce different kind of inequalities which adds to the invisibility and the plight for those at the margins (Drèze \& Sen, 2013, p. 231). In Uttar Pradesh and Bihar, the primary school enrolment is 23 percentage points lesser for girls belonging to scheduled castes and scheduled tribes than girls from non-scheduled caste and tribes (Department for International Development, 2005). Drèze in his book Uncertain Glory points out the hold of caste amongst the public institutions in the state of Uttar Pradesh by upper-caste Brahmins, where they hold 75 per cent of the top posts despite being just 20 per cent of the population.

\section{Capture by the Elites}

\section{"The wave of evil washes all our institutions alike." \\ - Ralph Waldo Emerson}

The institutions in an unequal society are ripe for capture by the elite because of the possibility of the actors being held accountable reduces highly in unequal societies (Green et al., 2013). The control of the elites over institutions gets deeply entrenched in the institutional memory, perversely impacting the development. During the colonial period, there were areas which were put under the zamindari system of land revenues. These areas suffer from poor provisioning of public goods like health-care, education, fractured social dynamics even today (Abhijit Banerjee \& Iyer, 2005). The colonial-era dawned in 1947! It would not be hyperbolic to say that such institutions cease to be institutions which function on the tenets of democratic governance failing on the metrics of accountability, responsiveness and legitimacy. Therefore, in light of the above arguments, it becomes imperative for institutions to exist which work towards reducing the perpetuated inequality by providing a voice to the marginalised. 


\section{Institutions for the Poor}

"If the misery of our poor be caused not by the laws of nature, but by

our institutions, great is our sin." - Charles Darwin

The poor need and deserve equitable provisioning of public goods like sanitation services, electricity, health-care, education to alleviate their suffering while at the same time they need institutions which give them some sort of legitimacy or authority to hold political institutions responsible to demand these rights. Through the 74th amendment to the Indian constitution, there was decentralisation of governance to better address such local needs, but the effectiveness of the devolution has been hampered by lack of finances and also the capacity of the functionaries of local bodies. (Aijaz, 2007; National Institute of Urban Affairs, 2015). However, in many cases, the poor suffer because they can't hold institutions responsible for oversight.

The case of the Dom Community who live on the peripheries of the power plant operated by the National Thermal Cooperation in Sonebadhra district in Uttar Pradesh buttresses this point. The Dom Community are scheduled caste and they have been employed as sweepers in the offices of the power plant for twenty-five years (Drèze \& Sen, 2013). It is a sheer irony that they live right next to where electricity is generated but they do not have any access to electricity. The Dom Community due to years of subjugation is afraid to even raise their voice and hold any institution be it the Gram Panchayat or the NTPC accountable for their plight. However, the establishment of institutions at the community level can be a way to address the inequality which the poor face and it would also improve the credibility of the existing political institutions. If democratic institutions are established within the communities where the urban poor live, it would help in the mobilisation for collective action. This idea might look very tempting, but such decentralisation of governance comes with caveats. If rules are not established which constrain the behaviour of the people of the community in such a way that the interests of the weakest sections of that community are not protected institutionally, who is to say that the influential class would not reinforce the iron law of oligarchy. 


\section{Safeguarding against Oligarchy}

These institutions would be rendered ineffective or become despotic unless careful thought is placed on the citizen participation which depends on details like the place or the environment of the meeting, who are invited for the meeting, who gets to speak, degree of inclusivity of the participation in the process of making a rule or a decision. If the institutional structure does not protect the exclusion of the marginalised, then this whole process would work to harm the social fabric of the community. This can be supplemented with the example of the meetings of the Kecamatan Development Project in Indonesia where communities were given aid by the World Bank to improve village infrastructure of their villages (A Banerjee \& Duflo, 2012). It was observed that out of the total adult population of the village only fifty attended, half of them being the "local elite" (Banerjee \& Duflo, 2012, p. 344). When it came to be participating in the deliberation of the decisions, only eight people deliberated with seven of them being from the local elite. The limitation of the deliberative process to only a select few which is at exhibit here goes against the tenets of participatory democracy. However, this was rectified with a little tweak in the way the meetings were conducted. In some randomly chosen villages, people were officially invited which saw the attendance jumping from the average of eight to sixty-five, with thirty-eight people belonging to the non-elite (A Banerjee \& Duflo, 2012). The increased attendance brought with itself increased participation of the non-elite in the deliberation on the decisions concerning the infrastructure of the villages.

\section{Power to the People but not All the Power}

The decentralisation of power into community-level institutions should be done by an authority which understands the dynamics of the community and the decentralisation should not happen at the cost of the people at the margins. The community-level institutions would empower the people at the margins by giving them power and accountability over the political institutions, however, certain rules like the effectiveness of the representation, choice of the representatives etc would constrain the behaviour and uphold the democratic tenets of governance.

\section{The Model}

The Settlement Improvement Committee (SIC) is a good example of operationalising the above arguments. The SICs were formed as part of the Engaged Citizens 
Responsive Cities (ECRC) project of the European Union (EU) which Participatory Research in Asia (PRIA) undertook in the informal settlements of the cities of Ajmer, Jhansi and Muzaffarpur. The informal settlements in these cities were often overlooked by the political institutions such as the urban local body when it came to delivery of basic services like toilets, drinking water, electricity connections. The lack of access deepened the inequality and when coupled with a lack of awareness or lack of will to exercise their rights over the unresponsive political institutions, it put the urban poor in a very disadvantageous position. The SICs were seen as an intervention which would empower the urban poor through collective action to remove the cloak of invisibility which often accompanies a poor person. The SICs were aimed towards:

- Improving direct accountability of the political institutions.

- Making the governance of the political institutions responsive.

- Improving the cohesion and participation of the communities by the active citizenry.

The SICs are run by urban poor of the informal settlement, but the constitution and initial rules of the composition of SICs were overlooked by PRIA. This was important because a decentralisation like this also has the tendency of being overtaken by only the influential members of the community. PRIA in the initial few visits identified the active local leaders if any, from within the community. The local leaders were generally people who have had a history of working for the community issues in the past. They were identified during informal interactions with the inhabitants of the settlements. The local leaders facilitated the very first community meeting in which the concept of a SIC was explained to the settlers and the PRIA also tried to understand the dynamics of the settlement. Then a second meeting of the community was called to identify the members of the SIC. The association with the SIC was on a voluntary basis however the homogeneity of the committee was seen as a red flag because it would have the possibility of excluding the voices of the unrepresented. In such cases, underrepresented demographics were engaged and requested to be part of the committee. PRIA was also conscious of including elders, women, girls as variety in representation would help capture the needs of the settlement in a holistic manner.

It is important here to note that though PRIA did not dictate terms to the SIC but it did oversee very closely the formation and operationalising of the rules regarding the: number of meetings per week or month, what tasks the members will have to 
undertake, the mandate of the SIC, who will be in charge of leading the SIC, how they will engage with the rest of the community and what are the priorities to be put forward by the SIC.

\section{The Evidence}

The evidence is presented as a case study of Mairi settlement in Ward No. 12 in the city of Jhansi in Uttar Pradesh where SIC was formed during the ECRC project. It the buttresses the argument that effective community-level organisations at grass-root levels can improve the credibility of existing political institutions by making them accountable, responsive and legitimate which would ultimately improve the standards of life of urban poor. Before the SIC was formed in the settlement, it suffered from erratic electricity, broken roads, lesser coverage of sanitation facilities like toilets, regular pickup of garbage etc. The existing political mechanism of the urban local body and the municipal councillor in charge of the settlement proved ineffective as many a time the urban poor due to their unequal standing could not hold them accountable. Upon the formation of the SIC, the community was mobilised and through the SIC pressure was built upon the municipal councillor of the area to address their issues. The effective community-level organisation ameliorated the situation of the inhabitants of the settlement. Concrete pathways were laid all across the settlement, a large number of inhabitants got access to toilets under Swachh Bharat Mission, the frequency of the 'safai karamcharis' and garbage disposal vans increased. The residents said that earlier while they would have done nothing about such issues, they now felt empowered enough to hold the service providers accountable.

The SIC of the settlement mobilised the community members to raise their voice to the Chief Medical Officer (CMO) regarding the issuance of health insurance cards. Despite meeting the eligibility criteria, no one in the settlement was covered by the state-sponsored health insurance scheme. When the CMO was apprised of the situation by the CMO, he assured them that their exclusion would be rectified. The settlement did not have any aanganwadi centres but the SIC members mobilised the people living in and around their settlement to approach the required authorities to submit an application for such a centre. This incident might seem very trivial for a person ensconced in privilege, but such institutions give the urban poor much strength and voice to remove the cloak of invisibility which accompanies their existence. The members of the community and the SIC revealed during the interaction that earlier 
government offices and institutions brought along with them a sense of intimidation. This allowed the chances of corruption through intermediaries and the possibility of being exploited as they were not aware of their rights. However, through the SIC they were able to apprise themselves of their rights which not get the provision of services, but it also improves the credibility of the political institutions of local governance.

\section{Conclusion}

"Political democracy cannot last unless there lies at the base of it social democracy. What does social democracy mean? It means a way of life which recognizes liberty, equality and fraternity as the principles of life." - B.R. Ambedkar

India as a political democracy has performed successfully on many aspects but the dream of it also being a social democracy as envisaged by Ambedkar isn't fulfilled. The ideals of democracy are compromised when people get robbed of their voice. With the growing inequality, a segment of the population finds itself on unequal platforms. Exclusion of an individual in democracy from decision making does not only harm the individual, but it also becomes a malaise for democracy. The issue is systemic and cyclical. If a household is living on the margins, the provision of basic services like education, sanitation, electricity, health care becomes an irreplaceable safety net for them. The presence of community-level institutions enables collective action and improves the cohesion of the community. But, more importantly, the institutional structure allows the members of the community a voice for their rights. This, in turn, makes the political institutions accountable because many a time, the poor would not hold the political institutions accountable because they simply do not know any better. The lack of accountability makes it possible for political institutions to overlook the unequal class.

After the 74th amendment to the constitution, the seat of local governance in cities and villages lie with the urban local bodies and gram panchayats respectively. There was devolution of functions to the urban local bodies, but the funds and functionaries have not been effectively transferred. It has been argued that the performance of local institutions of governance in the form of delivery of services becomes the defining metric for the legitimacy of institutions (Roos \& Lidström, 2014). If the governance of the local institutions is not considered legitimate by the people, it 
would mean little even if the broader democratic system worked well. Therefore, when the community level institutions work well, they would contribute towards making the local institutions legitimate as well as responsive which would make the democracy more inclusive and participatory.

However, the whole premise fails and even regresses if the community level institutions are not founded on the principles of democratic governance. The institutional design should safeguard the representation of the different demographics, the setting should not intimidate people from not participating which would stop the iron law of oligarchy from reinforcing itself. 


\section{References}

Aijaz, R. (2007). Challenges for Urban Local Governments in India, 97.

Banerjee, A, \& Duflo, E. (2012). Poor Economics: A Radical Rethinking of the Way to Fight Global Poverty. PublicAffairs. Retrieved from https://books.google.co.in/books?id=2dlnBoX4licC

Banerjee, Abhijit, \& Iyer, L. (2005). History, Institutions, and Economic Performance: The Legacy of Colonial Land Tenure Systems in India. The American Economic Review, 95(4), 1190-1213. Retrieved from http://www.jstor.org/stable/4132711

Department for International Development. (2005). Reducing Poverty by Tackling Social Exclusion.

Drèze, J., \& Sen, A. (2013). An Uncertain Glory: India and its Contradictions. Penguin Books Limited. Retrieved from https://books.google.co.in/books?id=5a2xdd KTWDoC

Green, D., Fried, M., \& Sen, A. (2013). From Poverty to Power: How Active Citizens and Effective States Can Change the World. Jacana. Retrieved from https://books.google.co.in/books?id=WFxonQEACAAJ

National Institute of Urban Affairs. (2015). A Study to Qualitatively Assess the Capacity Building Needs of Urban Local Bodies ( ULBs ), 116. Retrieved from http://niti.gov.in/writereaddata/files/document_publication/reportULB_o.pdf\%oAhttps://www.google.co.in/url?sa=t\&rct=j\&q=\&esrc=s\&source= web\&cd $=1 \& c a d=$ rja\&uact $=8 \&$ ved $=$ oahUKEwiOzIr8qfRAhWKPo8KHfWiCNoQFggeMAA\&url=http\%3A\%2F\%2Fniti.gov.in\%2Fwriter eaddata\%2Ffil 
Roos, K., \& Lidström, A. (2014). Local policies and local government legitimacy. The Swedish case. Urban Research and Practice, 7(2), 137-152. https://doi.org/10.1080/17535069.2014.910920

UNESCO. (n.d.). Poverty. Retrieved October 26, 2019, from http://www.unesco.org/new/en/social-and-humansciences/themes/international-migration/glossary/poverty/

World Bank. (2011). Perspectives on Poverty in India. https://doi.org/10.1596/978$0-8213-8689-7$ 